\title{
The Motivation of Serangan Community to Support the Development of Tourism at Serangan Village
}

\author{
$1^{\text {st }}$ I Made Darma Oka \\ Tourism Department \\ Politeknik Negeri Bali \\ Badung, Bali \\ madedarmaoka@pnb.ac.id
}

\author{
$2^{\text {nd }}$ I Nyoman Winia \\ Tourism Department \\ Politeknik Negeri Bali \\ Badung, Bali
}

\author{
$3^{\text {rd }}$ I Ketut Sadia \\ Tourism Department \\ Politeknik Negeri Bali \\ Badung, Bali
}

\begin{abstract}
A tourist destination needs to be professionally managed by involving all the stakeholders in order to get the maximum benefit, especially for the local community. In general, there are three factors that motivate the community to support the development of tourism; they are economic, social, and cultural factors. This article discusses the factors that motivate the local people to support the development of tourism at Serangan village. This research used qualitative and quantitative data collected by distributing questionnaires to and conducting an in-depth interview with those who are knowledgeable of the development of tourism at Serangan village. The research samples included 200 respondents determined using the accidental sampling technique. The data were analyzed using the confirmatory factor analysis technique to confirm the factors motivating the local community to support the development of tourism. The result of this research shows that the economic, social, and cultural factors have significantly contributed to the attempts made by the community to support the development of tourism; the economic factor is the most dominant one followed by the social and cultural factors, meaning that the economic factor is the main reason why the local community supports the development of tourism at the village. Therefore, it can be suggested that the government should empower the local people to participate in the development of tourism through elucidation, training and education programs to make them competitive in fulfilling the job vacancies available at the village. Thus, the local people need to prepare themselves earlier to improve or develop their knowledge and skill to win the competition.
\end{abstract}

Keywords--Motivate, Serangan commnity, tourism, development

\section{INTRODUCTION}

A tourist destination should be managed in such an integrated way that it will benefit all the stakeholders such as the government, the tourism agents, and the local people as the owner of the area. Serangan Village, as one of the tourist villages in Denpasar City, has made every attempt to develop its community-based tourism. The community-based tourism developed at Serangan Village needs the serious empowerment/participation of the local people; in other words, it should be developed by, from and for the local people. The process through which the participation of the local people appears can be viewed from two perspectives; they are (1) the involvement of the local people in the design, planning and implementation of the program; (2) the transformational participation as an objective to change the local people's condition from being weak and marginalized into being independent. According to Chambers (1995), this program reflects a new paradigm in development, namely the development which is "people-oriented, participatory, empowering and sustainable".

The motivation of the local people to participate in and support the development of tourism at Serangan Village is the result of internal and external processes involving every individual, causing them to follow the steps taken to support the development of tourism enthusiastically and persistently. The local people are aware that the development of tourism at their village benefits them. The internal factors which support the development of tourism can be in the forms of personality, attitude, experience and education or different expectations which can lead them to their future. One of the external factors is the environment where the local people live (Winardi, 2002). It is further stated that the factors which can contribute to motivation are: (1) the personal needs, (2) the goals and perception of someone or a group of people; (3) how such needs and goals can be realized. The fulfillment of those factors and providing the local people with the best motivate them to do the activities needed to develop tourism. Thus, the motivation of the people living at Serangan Village to support tourism has inspired them to participate. How strong or weak the local people's motivation to participate in the activities done to support the development of tourism depends on what advantages they can feel from the development of tourism.

Based on what was described above, it can be stated that there are several internal and external factors which have contributed to the local people's motivation to support the development of tourism at the village. This current study focuses on the factors motivating the local people to support the development of tourism at Serangan Village from the social, economic and cultural perspectives. Therefore, the theory of motivation and the concept of the community-based tourism (CBT) were used to analyze the local people's 
motivation to support the development of tourism at Serangan Village.

\section{RESEARCH METHOD}

The number of samples used in the current study was determined using the opinion proposed by Solimun (2002), in which it is stated that the number of the samples feasibly investigated through the factor analysis should be at least five times the total variables. 21 variables were used in the current study, and to make it more representative the respondents used totaled 200. The samples were taken using the accidental sampling technique, meaning that the respondents from whom information was obtained were accidentally met when the study was being conducted (Kusmayadi and Sugiarto, 2000: 141). The Confirmatory Factor Analysis (CFA) was used to analyze the factors motivating the local people to support the development of tourism at Serangan Village. The local people's motivation to support the development of tourism was made from variable $\mathrm{X} 1$ to $\mathrm{X} 21$. The three common factors, namely the economic factor (F1), the social factor (F2), and the social factor (F3), which had already been determined, led to several results of the confirmatory test. The factors and variables contributing to the local people's motivation to support the development of tourism at Serangan Village could be identified through the factor analysis.

\section{RESULTS AND DISCUSSION}

The people living at Serangan Village chose to be employed in the sector of tourism as the access to it was getting open. The growth of the development of tourism at Serangan Village could motivate the local people to actively participate in the development at the village. The real condition they felt that the development of tourism could support life caused the local people to participate in the activities of tourism. They were aware that the development of tourism at Serangan Village could improve their daily lives economically, socially and culturally, and made them more realistic when deciding to be employed in the sector of tourism.

The factors motivating the local people to support the development of tourism at Serangan village could be viewed from the interrelatedness of the economic, social and cultural factors and the interrelatedness of the variables. The three factors were used to measure the impact of the motivation of the local people to support the development of tourism at Serangan village, which, in the current study, are presented in the form of research variables determined to total 21 indicators. All the twenty one variables are the measureable indicators; they were supposed to contribute to the local people's motivation to support the development of tourism. Several tests were made to identify whether there was any correlation or not. The tests are (a) the Kaiser Meyer Olkin (KMO) test, which was used to identify the samples' feasibility, in which the factor analysis was considered feasible if KMO was higher than 0,05 (KMO>0,05); (b) the Barlett's Test of Spericity, which was used to test whether the variables in the samples varied or not.

The interrelatedness of the economic, social and cultural factors and the interrelatedness of the variables could be identified in the correlational matrix through the model of accuracy test using the Kaeser Meiyer Olkin (KMO) test and the Barlett's test. Simultaneously, the model of accuracy used showed 0.0837 and the Barlett's test showed 0.000. Then, the model of accuracy used in each factor was partially tested. The KMO test made in each variable forming the economic factor showed 0.861.The Barlett's test showed 0.000, meaning that it showed a significant value. The variables forming the social factor using the KMO test showed 0.717 and 0.000 using the Barlett's test, meaning that it showed a significant value. The cultural factor using the KMO test showed 0.699 and a significant value, namely 0.000 . The value obtained from the KMO test for every factor was $>0.05$, reflecting that the three factors had the model of accuracy to the analysis used, meaning that each factor contributed to the local people's motivation to support the development of tourism at Serangan Village. Then, the results of the tests made were interpreted based on the values appearing from the results of analysis after the factors investigated were feasibly considered entering the model of accuracy test. In the interpretation of analysis the other information, such as the information from the local people, obtained from the qualitative data source was also described.

The results of the statistical analysis and the data on the frequency of all the variables and the interpretation of each factor are more clearly described in a verbal narrative way as follows.

\begin{tabular}{|l|l|c|c|c|}
\hline F & \multicolumn{1}{|c|}{ Indicator of Variable } & $\begin{array}{c}\text { Correlational } \\
\text { Coefficient }\end{array}$ & Determined & Remarks \\
\hline \multirow{2}{*}{$\begin{array}{l}\text { The life of Serangan community could not be } \\
\text { separated from the activities of tourism (X1) }\end{array}$} & 0.717 & $>0.600$ & Significant \\
\cline { 2 - 5 } & $\begin{array}{l}\text { Serangan community fully supported that } \\
\text { Serangan village was decided as a tourist village } \\
\text { (X2) }\end{array}$ & 0.729 & $>0.600$ & Significant \\
\cline { 2 - 5 } $\mathrm{E}$ & $\begin{array}{l}\text { The decision of making Serangan a tourist } \\
\text { village really contributed to the local people's } \\
\mathrm{c}\end{array}$ & 0,769 & $>0.600$ & Significant \\
economy (X3) & $\begin{array}{l}\text { The decision of making Serangan a tourist } \\
\mathrm{n}\end{array}$ & 0.831 & $>0.600$ & Significant \\
$\mathrm{o}$ & $\begin{array}{l}\text { village could create new job opportunities for the } \\
\text { local people (X4) }\end{array}$ & & \\
\hline
\end{tabular}




\begin{tabular}{|c|c|c|c|c|}
\hline \multirow[t]{3}{*}{$\begin{array}{l}\mathrm{m} \\
\mathrm{i} \\
\mathrm{c}\end{array}$} & $\begin{array}{l}\text { The local people participated in/ employed in the } \\
\text { sector of tourism, resulting from the family } \\
\text { economic pressure (X5) }\end{array}$ & 0.788 & $>0.600$ & Significant \\
\hline & $\begin{array}{l}\text { Being employed in the sector of tourism could } \\
\text { improve the family income (X6) }\end{array}$ & 0.755 & $>0.600$ & Significant \\
\hline & $\begin{array}{l}\text { Being employed in the sector of tourism was } \\
\text { more prospective than being employed in the } \\
\text { other sectors such as in the sectors of agriculture, } \\
\text { fishery and so forth (X7) }\end{array}$ & 0.748 & $>0.600$ & Significant \\
\hline \multirow{7}{*}{$\begin{array}{l}\mathrm{S} \\
\mathrm{o} \\
\mathrm{c} \\
\mathrm{i} \\
\mathrm{a} \\
\mathrm{l}\end{array}$} & $\begin{array}{l}\text { The tourism agents gave priority to the local } \\
\text { people to be employed in the sector of tourism } \\
\text { (X8) }\end{array}$ & 0.632 & $>0.600$ & Significant \\
\hline & $\begin{array}{l}\text { The social interaction (the influence given by } \\
\text { friends) among the local people motivated the } \\
\text { local people to be employed in the sector of } \\
\text { tourism (X9) }\end{array}$ & 0.614 & $>0.600$ & Significant \\
\hline & $\begin{array}{l}\text { The local people positively welcome the decision } \\
\text { of making Serangan a tourist village (X10) }\end{array}$ & 0.762 & $>0.600$ & Significant \\
\hline & $\begin{array}{l}\text { Being employed in the sector of tourism could } \\
\text { increase the prestige of the local people and their } \\
\text { families (X11) }\end{array}$ & 0.660 & $>0.600$ & Significant \\
\hline & $\begin{array}{l}\text { The educational quality of the local people could } \\
\text { make them actively involved in the sector of } \\
\text { tourism (X12) }\end{array}$ & 0.620 & $>0.600$ & Significant \\
\hline & $\begin{array}{l}\text { The government had prepared the local } \\
\text { manpower to be employed in the sector of } \\
\text { tourism; they had been equipped with the } \\
\text { education and skill needed (X13) }\end{array}$ & 0.526 & $<0.600$ & $\begin{array}{c}\text { Insignifica } \\
\text { nt }\end{array}$ \\
\hline & $\begin{array}{l}\text { The role played by the government in } \\
\text { empowering the local people in the sector of } \\
\text { tourism was still poor (X14) }\end{array}$ & 0.686 & $>0.600$ & Significant \\
\hline \multirow{7}{*}{$\begin{array}{l}\mathrm{C} \\
\mathrm{u} \\
\mathrm{l} \\
\mathrm{t} \\
\mathrm{u} \\
\mathrm{r} \\
\mathrm{a} \\
\mathrm{l}\end{array}$} & $\begin{array}{l}\text { The positive impact of being employed in the } \\
\text { sector of tourism was that it could make the local } \\
\text { people aware of conserving the nature and their } \\
\text { culture (X15) }\end{array}$ & 0.717 & $>0.600$ & Significant \\
\hline & $\begin{array}{l}\text { Being employed in the sector of tourism could } \\
\text { widen their insight into their own culture (X16) }\end{array}$ & 0.613 & $>0.600$ & Significant \\
\hline & $\begin{array}{l}\text { So far the local people felt that they were } \\
\text { marginalized as job opportunities were made to } \\
\text { be less available for them (X17) }\end{array}$ & 0.807 & $>0.600$ & Significant \\
\hline & $\begin{array}{l}\text { The strict customs and traditions obstructed the } \\
\text { local people to be employed in the sector of } \\
\text { tourism (X18) }\end{array}$ & 0.728 & $>0.600$ & Significant \\
\hline & $\begin{array}{l}\text { The local people did not pay a serious attention to } \\
\text { the decision made by the government to promote } \\
\text { Serangan as a tourist village (X19) }\end{array}$ & 0.576 & $<0.600$ & $\begin{array}{c}\text { Insignifica } \\
\text { nt }\end{array}$ \\
\hline & $\begin{array}{l}\text { Being employed in the sector of tourism could } \\
\text { degrade their behavior; in other words, for } \\
\text { example, it could lead to prostitution (X20) }\end{array}$ & 0.722 & $<0.600$ & Significant \\
\hline & $\begin{array}{l}\text { The activities of tourism could not be separated } \\
\text { from the western culture which was not in } \\
\text { accordance with the local people's culture (X21) }\end{array}$ & 0.728 & $<0.600$ & Significant \\
\hline
\end{tabular}




\section{a. The Economic Factor}

From the result of the data analysis of the seven variables $(\mathrm{X} 1, \ldots \mathrm{X} 7)$ determined in the economic factor, it can be seen that each variable in the economic factor significantly contributed to the local people's motivation to support the development of tourism at Serangan village. The contribution of the accumulative value of all the variables in the economic factor showed 58.242, indicating that the eigen value of each variable shown through the value contributed by each component accumulatively and significantly contributed to the local people's motivation to support the development of tourism at Serangan village. The respondents coming from Serangan village stated that the lives of many local people could not be separated from the activities of tourism; in other words, the lives of many local people were highly dependent on the activities of tourism. This was also revealed by Cole (2012) in his study, in which he stated that the lives of most Balinese people $(80 \%)$ were dependent on the activities of tourism. Therefore, the activities of tourism at Serangan village should be maintained to make it sustainable and able to improve the welfare of the local people in particular and that of the Balinese people in general. Sutrisna (2011), in his study, stated that the sector of tourism had been able to create job opportunities for the local people through different types of businesses related to tourism. Sadia and Oka (2012) also stated that the economic factor motivated $91.58 \%$ of those employed in the cruise; the non-economic factor motivated the rest, namely $8.42 \%$. Therefore, it can be stated that the economic factor, which was getting higher, dominantly motivated the local people to support the development of tourism at Serangan village. Oka and Pugra (2017) also mentioned that those who were involved in the sector of tourism could improve their family income.

\section{b. The Social Factor}

The result of the test of the social factor showed the value which was higher than that determined using the model of analysis used, namely 0.05 , meaning that, statistically, the level of the significance of the model accuracy of the social factor was 0.000 .Then, the result of analysis of the social factor involving variables $\mathrm{X} 8, \ldots \mathrm{X} 14$ showed the eigen value of one component of the social factor could explain the totaling diversity, namely 41.762 , meaning that the featuring value of the social factor affected all the variables in the social factor. The impact of each variable on the local people's motivation to support the development of tourism at Serangan village could not be separated from the social factor shown by the matrix of the component value. In general, the matrix component of the social factor obtained was higher that what had been determined, namely (0.600), except X13, namely the variable that the government had prepared the local manpower to be employed in the sector of tourism through education/training (X13), resulting from the fact that the local people had been aware of the role played by the government in providing them with education/training in the sector of tourism was still poor. The local people really needed this type of education/training to make them perfectly able to manage and participate actively in the sector of tourism developing at the village. Oka, et al.
(2015) stated that being employed in the sector of tourism could improve the social status of the local people as they were considered being able to communicate and socialize with tourists who were socially and culturally different from them. Apart from that, Oka et al. (2017) mentioned that the local people living at Serangan should be willing to prepare themselves earlier without disturbing the role played by the government in providing them with education/training in tourism. The local people should always do their best to improve their competencies in order to be more competitive and able to occupy and create the job opportunities available at their own village.

\section{c. The Social Factor}

The value obtained from the cultural factor was higher than 0.05 , namely 0.699 , showing that, statistically, the component of the cultural factor had more accuracy in the model of analysis than that of the other factors with a significant value, namely 0.000 . The result of the factor analysis of the seven variables observed (X15, ...X21) showed one factor component which determined the variables under the cultural factor with the eigen value which could explain the totaling diversity, namely $49.319 \%$. Viewed from the contribution made, all the variables in the cultural factor significantly contributed to the local people's motivation to support the development of tourism at Serangan village, meaning that the cultural factor played a highly important role in motivating the local people to be employed in the sector of tourism. However, there was one variable which did not significantly contribute to the local people's motivation to support the development of tourism at Serangan. They did not pay a serious attention to the decision made by the government to determine that Serangan was a tourist village (X19).

The local people's awareness of conserving their culture appeared when they felt that the development of tourism at their village was positive. They were getting to be more active in maintaining the cleanliness of the environment where they lived. They became motivated to pay attention to the cleanliness around Sakenan Temple, Dalem Cemara Temple and the surrounding beaches. Apart from that, the local people were getting to be more active in conserving the culture they had by creating the activities through which their children could learn their culture, conserve the indigenous traditional dance, which is specific to Serangan, that is, Telek dance. They also established a group of gamelan palyers 'sekehe gamelan'. It was expected that the activities mentioned above could support the activities of tourism at Serangan village to be sustainable; in this way, tourism may also be enjoyed by the future generation.

\section{CONCLUSIONS}

The factors which motivated the local people to support the development of tourism at Serangan village were the economic factor, social factor and cultural factor. They significantly contributed to the local people's motivation to support tourism at their village. The statistical test showed that the economic factor most dominantly motivated the local people to support the development of tourism, followed by the social factor and 
cultural factor, meaning that the main object of the local people to support the development of tourism at their village was the need for being able to fulfill their family needs. Out of the 21 indicators of the variables tested in the current study, 19 (variables) really dominantly contributed to the local people's motivation to support the development of tourism, except the variable which showed what the government had done to prepare the local manpower to be employed in the sector of tourism, namely the education/training it had undertaken for the local people (X13), and the variable showing that the local people did not pay a serious attention to the decision made by the government to determine Serangan as a tourist village (X19). It is suggested to the government that it should play a more active role in providing education and training in tourism to the local people living at Serangan village in particular. In this way, the local people would not feel marginalized any longer; instead, they would feel that they were useful to their village, causing them to be more aware that they should also maintain and conserve the culture they had to support the sustainability of the tourism developed at Serangan village.

\section{ACKNOWLEDGMENTS}

We are saying thankful to "Direktorat Riset Peneliian dan Pengabdian Masyarakat, Direktorat Jenderal Penguatan Penguatan Riset dan Pengembangan Kementerian Riset, Teknologi, dan Pendidikan Tinggi". We are saying thankful to all informen for providing me information and kind support throughout the research work. And we are also saying thankful to the God.

\section{REFERENCES}

[1] Cole, S. 2012. A Political Ecology of Water Equity and Tourism: A Case Study From Bali. Annals of Tourism Research. 39 (2), 1221-1241

[2] Geriya, S.S. 2006. Profil Pendidikan Wanita dari Masa ke Masa. Jurnal Studi Gender Srikandi. VI (1), 42-49.

[3] Hasibuan, M. 2005. Managemen Dasar, Pengertian dan Masalah. Jakarta: Bumi Aksara. Ed. Revisi.

[4] Oka, I.M.D. and Pugra, I.W., 2017. The Impacts of Balinese Women Working in Cruise Ship. International Journal of Applied Sciences in Tourism and Events, 1(1), p.51.
[5] Oka, I M.D.; Sadia, I Ketut; Pugra, I Wayan. Integrated Practice Learning Model To Improve Waiter/S' Competency On Hospitality Study Program, Politeknik Negeri Bali. International Journal of Applied Sciences in Tourism and Events, [S.1.], v. 1, n. 2, p. 171, dec. 2017 ISSN 2580-5592. Available at: <http://ojs.pnb.ac.id/index.php/IJASTE/article/view/665>. Date accessed: 26 June 2018.

[6] Oka, I.M.D., Antara, M. and Mudana, I.G., 2015. Socio-Cultural Implication of Balinese Women Working On Cruise Ship. Journal of Cultural Studies, 8(3).

[7] Oka, I M. D.; Winia, I Nyoman; Sadia, I Ketut. Pemetaan Potensi Pariwisata Dalam Mendukung Pengembangan Pariwisata Di Desa Serangan. Bhakti Persada: Jurnal Aplikasi IPTEKS, [S.L.], V. 4, N. 1, P. 47-54, June 2018. ISSN 2580-5606. Available At: <Http://Ojs.Pnb.Ac.Id/Index.Php/BP/Article/View/854>. Date Accessed: 23 June 2018.

[8] Oka, I M.D.; Winia, I Nyoman; Pugra, I Wayan. Pemberdayaan Masyarakat Melalui Pelatihan Pengolahan Masakan Seafoods Untuk Menunjang Pariwisata Di Desa Wisata Serangan. Bhakti Persada: Jurnal Aplikasi IPTEKS, [S.1.], v. 1, n. 1, p. 62, feb. 2017. ISSN 2580-5606. Available at: 〈http://ojs.pnb.ac.id/index.php/BP/article/view/250〉. Date accessed: 26 june 2018.

[9] Sadia, I.K. and Oka, I.M.D., 2012. Motivasi Tenaga Kerja Bali Bekerja di Mediterranean Shipping Company (MSC). Jurnal Sosial Humaniora, 2(3), pp.221-236.

[10] Murni, Ni Gst Nym Suci; Mudana, I Gede; Suria Antara, Dewa Made. Ideological Discourses on Environment in Bali Tourism Development. International Journal of Applied Sciences in Tourism and Events, [S.1.], v. 1, n. 2, p. 104, dec. 2017. ISSN 2580-5592. Available at: <http://ojs.pnb.ac.id/index.php/IJASTE/article/view/658>. Date accessed: 26 june 2018.

[11] Murni, N.G.N.S dan Oka, I.M.D. 2009. Persepsi Tokoh Masyarakat terhadap perempuan yang bekerja pada Spa di Kawasan Pariwisata Kuta. Jurnal Manajemen Pariwisata. Vol 11 (1), 22-36

[12] Sukeni, N. N. 2006. Dampak Pariwisata terhadap Gender di Bali. Jurnal Studi Gender Srikandi. VI. (1), 1-13.

[13] Suryandaru, Y. S. 2010. Hegemoni dan Reproduksi Kekuasaan dalam Perdagangan Perempuan (Trafficking) untuk Prostitusi. Jurnal Masyarakat Kebudayaan dan Politik. 14 (2), 35-50.

[14] Sri, P. A. A. 2013. Faktor-faktor yang Memotivasi Perempuan sebagai Pengelola Pondok Wisata di Kelurahan Ubud, Kecamatan Ubud, Kabupaten Gianyar. Analisis Pariwisata. 13 (1), 1-10.

[15] Solimun. 2002. Multivariate Analisis, Structural Equation Modeling (SEM) Lisrel dan Amos. Malang: Brawijaya FMIPA. 